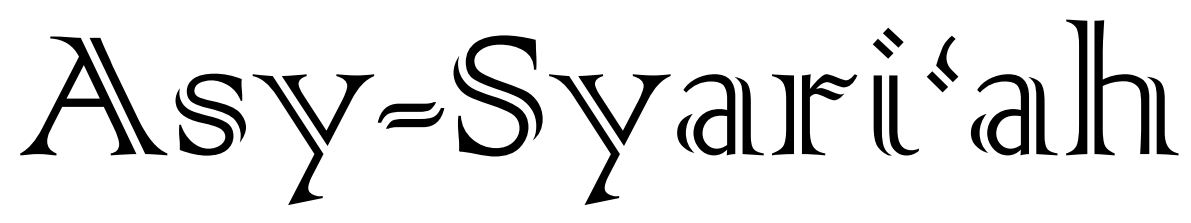

- $\quad$ The Role of Religious Court in Islamic Law Reform in Indonesia

$(125-134)$ Amran Suadi

- Rechtvinding tentang Waris Beda Agama di Pengadilan Agama ( $135-158)$ Kota Bandung Siah Khosyi'ah dan Aan Tsamrotul Fuadah

- Dualisme Kedudukan dan Tanggung Jawab Notaris dalam ( $159-170)$ Tatanan Sistem Hukum Nasional Isis Ikhwansyah dan Indra Prayitno

- Nilai-Nilai Keislaman dalam Konstitusi Kesultanan Ngayogyakarta Hadiningrat

Abdul Rohim Al Wafi

- Anotasi Putusan Dissenting Opinion dalam Putusan Kasasi Taufik Maulani

- Dampak Poligami Siri Terhadap Kehidupan Keluarga di Desa Cigugur Girang, Bandung Barat Ade Darmawijaya

- Azas-Azas dan Landasan Distribusi Pendapatan dalam Islam $(221-232)$ Rani Mulyani dan Iwan Setiawan

- Eksistensi Riba dalam Investasi Wakaf Uang di Luar Bank (233-244) Syari'ah

Khoir Affandi

- Hak Pendidikan bagi Penyandang Disabilitas dalam Perspektif Hukum Perdata dan Hak Asasi Manusia

Ikbar Maulana Malik

- Perspektif Hukum Islam dalam Penyelesaian Sengketa Melalui ( $257-280$ ) Mediasi di Badan Penyelesaian Sengketa Konsumen Kota Mataram Irma Istihara Zain 


\section{Asy-Syauri'ah}

Volume 21, Number 2, 2019

\section{EDITOR-IN-CHIEF}

Ine Fauzia

\section{EDITORIAL BOARD}

Sofyan al-Hakim, UIN Sunan Gunung Djati Bandung, Indonesia Deni Kamaludin Yusup, UIN Sunan Gunung Djati Bandung, Indonesia Meria Utama, Fakultas Hukum Univrsitas Sriwijaya, Indonesia Dewi Mayaningsih, UIN Sunan Gunung Djati Bandung, Indonesia Andrey Sujatmiko, Fakultas Hukum Universitas Trisakti, Jakarta, Indonesia Hetty Hassanah, Universitas Komputer Indonesia, Indonesia

\section{PEER-REVIEWERS}

Muhammad Irfan Helmy, IAIN Salatiga, Semarang, Indonesia Ahmad Ali Nurdin, UIN Sunan Gunung Djati Bandung Tajul Arifin, UIN Sunan Gunun Djati Bandung, Indonesia Mohamad Anton Athoillah, UIN Sunan Gunung Djati Bandung, Indonesia Mrs. Renny Supriyatni, Universitas Padjadjaran, Indonesia Ahmad Tholabi Karlie, UIN Syarif Hidayatullah Jakarta, Indonesia Ija Suntana, UIN Sunan Gunung Djati Bandung, Indonesia Zezen Zaenal Mutaqin, University of California, Los Angeles, United States Ahmad Fathonih, UIN Sunan Gunung Djati Bandung, Indonesia Rahman Syamsuddin, Universitas Islam Negeri Alauddin Makassar, Indonesia

\section{PROOFREADER/DESIGN COVER}

Nanang Sungkawa

\section{LAYOUT EDITOR}

Opik Rozikin

Asy-Syari' ah has been accredited based on the determination of Director General of Research and Development Strengthening, Ministry of Research, Technology and Higher Education of Republic of Indonesia, No. 14/E/KPT/2019 (valid until 2023). 


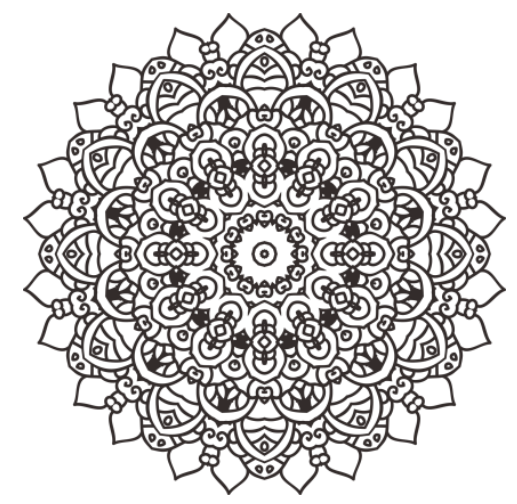

\title{
ANOTASI PUTUSAN DISSENTING OPINION DALAM PUTUSAN KASASI
}

\author{
Taufik Maulani \\ Pengadilan Tinggi Agama Jawa Barat \\ Email: Ocha.bogor@gmail.com
}

\begin{abstract}
Judges 'decisions in court are the core of the parties' agreement. Decision of the Supreme Court of the Republic of Indonesia Number: 579/K/AG/2010 concerning Settlement of Inheritance Disputes. Trying out this research is trying to explain, is there a legal basis for differences of opinion in the judicial decision in Indonesia. The juridicalnormative method was used in analyzing this study. Primary and secondary data sources from the decision of the Supreme Court, Jurisprudence Books and Legislation Regulations are sources of data in completing this research. The results showed first, the legal basis for the difference of opinion in the court's decision in Indonesia; secondly, the legal basis / consideration of the cassation panel of judges who reject the cassation filed by the parties in the decision Number: 579/K/AG/2010 is an unacceptable lawsuit because the cassation applicants are not the heirs who are experts and heirs who are trying exist in KHI regulated in Presidential Instruction Number 1 of 1991; and three, the legal implications of differences of opinion that proved positive as the judges' hard efforts in compiling the normative legal grounds and considerations, description, basis, and legal liability to take a fair decision, including the decision of cassation Number: 579/K/AG/ 2010 who refused to give heir to the heirs decided that the gift really took effect before the birth of KHI in 1991.
\end{abstract}

Key Words: dissenting opinion, decision, inheritance, substitutes parties 
Abstrak: Putusan hakim di pengadilan merupakan inti penyelesaian sengketa bagi pihak-pihak yang berperkara. Penelitian ini berfokus pada perbedaan pendapat (dissenting opinion) dalam Putusan Kasasi Mahkamah Agung Republik Indonesia Nomor: 579/K/AG/2010 tentang Penyelesaian Sengketa Waris. Sehingga penelitian ini mencoba menjelaskan, apakah ada dasar hukum dissenting opinion dalam putusan pengadilan di Indonesia. Metode yuridis-normatif digunakan dalam menganalisis penelitian ini. Sumber data primer dan sekunder dari putusan Mahkamah Agung, Kitab-kitab Fikih dan Peraturan Perundang-undangan menjadi sumber data dalam melengkapi penelitian ini. Hasil penelitian menunjukkan pertama, dasar hukum kebolehan adanya dissenting opinion dalam putusan pengadilan di Indonesia; kedua, dasar/pertimbangan hukum majelis hakim kasasi yang menolak permohonan kasasi yang oleh para pihak dalam putusan Nomor: 579/K/AG/2010 adalah gugatan tidak dapat diterima karena para pihak pemohonan kasasi bukan para pihak ahli waris yang sebenarnya dan ahli waris pengganti baru ada dalam KHI yang diatur dalam Inpres Nomor 1 Tahun 1991; dan ketiga, implikasi hukum dari adanya dissenting opinion terbukti positif sebagai usaha keras para hakim dalam menyusun dasar dan pertimbangan hukum secara normatif, uraian, dasar, dan pertimbangan hukum untuk mengambil sebuah putusan yang adil, termasuk pula putusan kasasi Nomor: 579/K/AG/2010 yang menolak memberikan harta waris kepada ahli waris pengganti sudah benar karena ketentuan itu belaku sebelum lahirnya KHI Tahun 1991.

Kata Kunci: dissenting opinion, putusan, waris, ahli waris pengganti 


\section{Pendahuluan}

Identitas perkata dalam Putusan Kasasi Mahkamah Agung Republik Indonesia Nomor: 579/K/AG/2010 tersebut berkenaan dengan penyelesaian sengketa waris yang melibatkan Rogayah binti Ahmad, Maimunah binti Ahmad, dan Nurbayah binti Ahmad sebagai Pemohon Kasasi dahulu Tergugat I, III dan IV/Para Pembanding melawan M. Soleh bin Abdul Hamid dan teman-teman sebagai Termohon Kasasi dahulu Para Penggugat dan Tergugat II.

Kasus posisi Putusan Kasasi Mahkamah Agung Republik Indonesia Nomor: 579/K/AG/2010 dilatarbelakangi perist iwa hukum yang dijadikan dasar gugatan dalam perkara gugatan waris yaitu Ahmad bin Sa'i menikah dengan Salimah binti Soleh tahun 1919 dan Ahmad bin Sa'i telah meninggal dunia pada tanggal 10 Januari 1993, karena sakit dikebumikan di Sekayu dan isterinya Salimah binti Soleh telah meninggal dunia pada tanggal 20 Februari 1982, karena sakit dan dikebumikan di Sekayu, Kabupaten Musi Banyuasin.

Kedua orang tua almarhum Ahmad bin Sa'i dan orang tua almarhumah Salimah binti Soleh telah meninggal dunia terlebih dahulu dari almarhum Ahmad bin Sa'i dan almarhumah Salimah binti Soleh. Almarhum Ahmad bin Sa'i dan almarhumah Salimah binti Soleh dan selama pernikahan tidak pernah bercerai. Almarhum Ahmad bin Sa'i dan almarhumah Salimah binti Soleh juga semasa hidupnya mempunyai keturunan.

Ahmad bin Sa'i meninggal dunia pada tanggal 10 Januari 1993, sedangkan isterinya meninggal dunia lebih dahulu pada tanggal 20 Februari 1982. Keduanya meninggalkan ahli waris sebanyak 4 orang anak yang masih hidup yaitu $\mathrm{Hj}$. Maimunah binti Ahmad, Arbain bin Ahmad, Rogayah binti Ahmad, dan Nurbayah binti Ahmad. Sedangkan 3 anak lainnya telah meninggal dunia lebih dahulu, yaitu Abdullah bin Ahmad meninggal dunia pada tahun 1974, Abdul Hamid bin Ahmad, meninggal dunia pada tahun 1986, dan Anwar bin Ahmad, meninggal dunia pada tahun 1962. Namun ketiga anak yang telah meninggal lebih dahulu tersebut telah meninggalkan 15 orang cucu (6 cucu laki-laki dan 9 cucu perempuan) yang kemudian nanti menjadi para pihak ahli waris pengganti.

Selain itu, almarhum Ahmad bin Sa'i dan almarhumah Salimah binti Soleh juga meninggalkan harta warisan berupa Satu bidang tanah pekarangan yang berukuran panjang 33,70 $\mathrm{m}$ dan lebar 15,40 $\mathrm{m}$ diatas tanah tersebut berdiri 1 (satu) unit rumah panggung berukuran panjang $26 \mathrm{~m}$, lebar 6,50 m, atap genteng dinding papan lantai papan terletak di Jalan Merdeka RT.05, RW.02, Kelurahan Soak Baru, Kecamatan Sekayu, Kabupaten Musi Banyuasin, dengan batas-batas sebagai berikut: sebelah Barat berbatasan dengan Jalan Merdeka Sekayu, sebelah Timur berbatasan dengan tanah milik Lukman Hakim Abdullah, sebelah Utara berbatasan dengan tanah milik H. Yazid bin Suud (Alm.), dan sebelah Selatan berbatasan dengan tanah milik Halim bin Jahudin dan tanah milik Arbi bin Nuri. 
Harta warisan almarhum Ahmad bin Sa'i dan almarhumah Salimah binti Soleh tersebut diatas belum pernah dibagikan kepada ahli waris yang berhak menerimanya baik secara Hukum Islam maupun secara Hukum Adat. Sedangkan harta warisan tersebut di atas sepenuhnya dikuasai oleh Rogaya binti Ahmad Tergugat I dengan dalih dapat membeli dari Arbain bin Ahmad Tergugat II, Hj . Maimunah binti Ahmad Tergugat III dan Nurbaya binti Ahmad Tergugat IV, dan kesepakatan jual beli tersebut tanpa sepengetahuan dari para Penggugat yang juga ahli waris dari almarhum Ahmad bin Sa'i dan almarhumah Salimah binti Soleh.

Kemudian Pihak Penggugat telah berulang kali melakukan perdamaian kepada pihak Tergugat dengan jalan musyawarah dan mufakat baik melalui pemerintah setempat maupun melalui jalur kekeluargaan namun tidak berhasil, bahkan pernah juga para Penggugat melakukan sanggahan kepada Bapak Camat Sekayu sekiranya surat jual beli dan pengakuan hak No. 593/134/II/2008 tanggal 22 Februari 2008 yang diajukan oleh Tergugat dibatalkan karena objek sengketa tersebut adalah harta warisan almarhum Ahmad bin Sa'i dan almarhumah Salimah binti Soleh yang belum dibagikan kepada ahli waris yang lainnya;

Berdasarkan dasar gugatan di atas, para Penggugat memohon kepada Pengadilan Agmana Sekayu, Kabupaten Banyuasin. Terhadap gugatan tersebut, Tergugat I, III, dan IV mengajukan eksepsi yang pada pokoknya atas dalil-dalil sebagai berikut: pertama, almarhum orang tua kami (Ahmad bin Sa'i dan Salimah binti Soleh) mempunyai anak sebagai ahli waris dan mempunyai cukup banyak harta peninggalannya; kedua, secara resmi harta peninggalan almarhum orang tua kami, belum pernah dibagikan atau pun diberikan kepada kami anakanaknya sebagai ahli waris maupun kepada cucunya; ketiga, almarhum orang tua kami tidak saja meninggalkan sebidang tanah pekarangan berikut di atasnya berdiri sebuah rumah panggung tua yang terletak di Jalan Merdeka RT.05, RW.02, Kelurahan Soak Baru, Kecamatan Sekayu, akan tetapi masih banyak lagi peninggalan lainnya berupa kebun buah, kebun karet, tanah kosong/belukar yang terletak di Sekayu maupun Talang Piase dan lainlain; keempat, kurang lebih awal tahun 1994, para ahli waris telah bermusyawarah akan menjual sebuah panggung tua berikut sebidang tanah pekarangannya yang terletak di Jalan Merdeka RT.05, RW.02, Kelurahan Soak Baru, Kecamatan Sekayu kepada para ahli waris maupun cucu almarhum orang tua, termasuk telah pernah diberitahukan dan di tawarkan kepada saudara keponakan kami M. Soleh, S.E. bin Abdul Hamid supaya berkenan membelinya.

Namun demikian pada waktu itu tidak ada satupun anak maupun cucu almarhum orang tua kami yang mau membeli rumah tersebut. Kemudian setelah beberapa kali telah dimusyawarahkan dan disepakati agar rumah tersebut jangan diperjualbelikan kepada orang lain selain anak maupun cucu almarhum orang tua kami. Sehingga akhirnya berdasarkan hasil musyawarah dan disepakati secara kekeluargaan, bahkan rumah tersebut akan dijual dan diberikan kepada saudara kami Rogayah binti Ahmad. 
Selanjutnya setelah semuanya disepakati dan diselesaikan, maka jual belinya secara resmi baru dibuatkan surat pernyataan jual beli pada tanggal 17 Januari 1995 yang dibuat diatas kertas segel Tahun 1994 yang ditandatangani oleh cucu-cucu almarhum orang tua kami.

Beradasarkan musyawarah dan kesepakatan secara kekeluargaan tersebut, maka jual beli sebuah rumah panggung tua berikut sebidang tanah pekarangannya sebagaimana tersebut diatas adalah sah menurut hukum dan legal formalnya telah dibuatkan surat pengakuan hak dan surat keterangan berdasarkan atas hak surat pernyataan jual beli diatas segel yang telah ditandatangani dan diketahui oleh semua pihak yang terkait dan oleh aparat pemerintah yang berwenang (Lurah dan Camat). Oleh karena itu, Tergugat menolak anggapan yang menyatakan bahwa jual beli rumah tersebut tanpa musyawarah dan tanpa kesepakatan serta tanpa sepengetahuan para ahli waris dan cucu-cucu almarhum orang tua kami.

Adapun fakta hukum yang terdapat dalam perkara tersebut adalah telah ditemukan beberapa fakta hukum yang dapat dijadikan bahan pertimbangan oleh hakim untuk penyelesaian perkara tersebut, diantaranya ialah:

1. Ahmad bin Sa'i menikah dengan Salimah binti Soleh tahun 1919 dan Ahmad bin Sa'i telah meninggal dunia pada tanggal 10 Januari 1993, karena sakit dikebumikan di Sekayu dan isterinya Salimah binti Soleh telah meninggal dunia pada tanggal 20 Februari 1982.

2. Almarhum Ahmad bin Sa'i dan almarhumah Salimah binti Soleh semasa hidupnya mempunyai keturunan ahli waris pengganti sebanyak 7 orang sebagaimana telah disebutkan di atas.

3. Almarhum Ahmad bin Sa'i dan almarhumah Salimah binti Soleh meninggalkan harta warisan berupa Satu bidang tanah pekarangan yang berukuran panjang $33,70 \mathrm{~m}$ dan lebar $15,40 \mathrm{~m}$ diatas tanah tersebut berdiri 1 (satu) unit rumah panggung berukuran panjang $26 \mathrm{~m}$, lebar 6,50 m, atap genteng dinding papan lantai papan terletak di Jalan Merdeka RT.05, RW.02, Kelurahan Soak Baru, Kecamatan Sekayu, Kabupaten Musi Banyuasin.

4. Harta warisan almarhum Ahmad bin Sa'i dan almarhumah Salimah binti Soleh tersebut belum pernah dibagikan kepada ahli waris yang berhak menerimanya baik secara Hukum Islam maupun secara Hukum Adat.

5. Harta warisan tersebut diatas dikuasai oleh sepenuhnya oleh Rogaya binti Ahmad Tergugat I.

Berdasarkan pertimbangan tersebut, pada pengadilan tingkat pertama, majelis hakim Pengadilan Agama Sekayu telah mengambil putusan, yaitu putusan Nomor: 212/Pdt.G/2008/PA.Sky tanggal 24 Februari 2009 M., bertepatan dengan tanggal 28 Shafar $1430 \mathrm{H}$., yang dalam amarnya menyebutkan dalam eksepsi dari Tergugat I, III dan IV dikabulkan untuk sebagian dan ditolak untuk selain dan selebihnya. 
Selanjutnya pada pengadilan tingkat banding, putusan majelis hakim pada tingkat pertama tersebut telah diperbaiki amarnya yang mengenai besarnya bagian ahli waris dengan putusan Nomor: 09/Pdt.G/ 2009/PTA.Plg tanggal 10 Desember 2009 M., bertepatan dengan tanggal 23 Dzulhijah $1430 \mathrm{H}$., yang perbaikan amarnya menyebutkan dan menetapkan bahwa bagian masing- masing ahli waris almarhum Ahmad bin Sa'i adalah sebanyak 7 orang sebagaiama telah disebutkan di atas.

Kemudian pada pengadilan tingkat kasasi, Mahkamah Agung memberikan amar yang menolak permohonan kasasi dari para Pemohon Kasasi (Rogayah binti Ahmad, Hj. Maimunah binti Ahmad, Nurbayah binti Ahmad) dan membebankan biaya kepada Para Pemohon Kasasi/ Tergugat I, III dan IV sebesar Rp. 500.000,- (lima ratus ribu rupiah).

Adapun yang menjadi pertimbangan majelis hakim tingkat kasasi pada Mahkamah Agung dalam Putusan Nomor: 579 K/AG/2010 adalah mengenai alasan ke-1 sampai dengan ke-3 Bahwa alasan tersebut tidak dapat dibenarkan, karena judex facti tidak salah menerapkan hukum, lagi pula mengenai penilaian hasil pembuktian yang bersifat penghargaan tentang suatu kenyataan, hal mana tidak dapat dipertimbangkan dalam pemeriksaan pada tingkat kasasi, karena pemeriksaan dalam tingkat kasasi hanya berkenaan dengan adanya kesalahan penerapan hukum, adanya pelanggaran hukum yang berlaku, adanya kelalaian dalam memenuhi syarat-syarat yang telah diatur atau diwajibkan oleh peraturan perundang-undangan yang mengancam kelalaian itu dengan batalnya putusan yang bersangkutan atau bila pengadilan tidak berwenang atau melampaui batas wewenangnya sebagaimana yang dimaksud dalam Pasal 30 UndangUndang Nomor 14 Tahun 1985 tentang Mahkamah Agung sebagaimana telah diubah dengan Undang-Undang Nomor 4 Tahun 2004 dan perubahan kedua dengan UndangUndang Nomor 3 Tahun 2009.

Di samping itu, majelis hakim tingkat kasasi pada Mahkamah Agung dalam Putusan Nomor: 579 K/AG/2010 juga memiliki pertimbangan dalam sidang musyawarah Majelis Hakim Agung di Mahkamah Agung RI, terjadi adanya perdapat yang berbeda dari Hakim Agung Drs. H. Habiburrahman, M.Hum., yang berpendapat bahwa gugatan tidak dapat diterima, para pihak bukan pihak, karena ahli waris pengganti baru ada pada tahun 1991, sejak diberlakukannya Kompilasi Hukum Islam yang dalam Pasal 185 mengatur adanya ahli waris pengganti.

Selanjutnya, majelis hakim tingkat kasasi pada Mahkamah Agung dalam Putusan Nomor: $579 \mathrm{~K} / \mathrm{AG} / 2010$ juga menambahkan dalam pertimbangannya bahwa sekalipun ada dua pendapat yang berbeda tersebut (dissenting opinion) tentang perihal akibat hukumnya, namun demi terciptanya rasa keadilan dan ketentraman keduanya, permohonan kasasi yang diajukan oleh para Pemohon Kasasi (Rogayah binti Ahmad, $\mathrm{Hj}$. Maimunah binti Ahmad, dan Nurbayah binti Ahmad) tersebut harus DITOLAK. Oleh 
karena permohonan kasasi dari para Pemohon Kasasi ditolak, maka para Pemohon Kasasi dihukum untuk membayar biaya perkara dalam tingkat kasasi ini.

Masalah hukum yang cukup menarik untuk dikaji dan dianalisis dalam majelis hakim tingkat kasasi pada Mahkamah Agung dalam Putusan Nomor: 579 K/AG/2010 ini adalah dissenting opinion terjadi pada majelis hakim kasasi tentang persyaratan, keabsahan, dan pertimbangan hukum memberikan warisan kepada ahli waris pengganti. Selain itu, menariknya kedudukan para pihak yang mengajukan perkara gugatan waris juga berkedudukan sebagai ahli waris pengganti, di mana ketentuan tentang ahli waris pengganti baru ada pada tahun 1991 (setelah pemberlakuan KHI).

Persoalan krusial dalam putusan tersebut adalah bagaimana tinjauan yuridis terhadap Putusan Kasasi Mahkamah Agung Republik Indonesia Nomor: 579/K/AG/2010 tentang penyelesaian sengketa waris bagi ahli waris pengganti, yang difokuskan terhadap kedudukan para pihak yang mengajukan gugatan waris merupakan para pihak yang kedudukannya sebagai ahli waris pengganti daripada para ahli waris sebenarnya yang telah meninggal dunia sebelum adanya ketentuan mengenai ahli waris penggant i sebagaimana diatur pada Pasal 185 tentang ahli waris pengganti dalam Kompilasi Hukum Islam (KHI) yang baru diberlakukan tahun 1991.

\section{Metodologi}

Metode yuridis-normatif digunakan dalam menganalisis penelitian ini. Metode ini mencoba menjelaskan penelitian ini secara normative berdasarkan aturan-aturan dan teori yang berkaitan dengan penelitian ini. Sedangkan, sumber data primer dan sekunder dari putusan Mahkamah Agung, Kitab-kitab Fikih dan Peraturan Perundang-undangan menjadi sumber data dalam melengkapi penelitian ini. Penggunaan sumber data primer dan sekunder dimaksudkan untuk melengkapi penjelasan dalam penelitian ini.

\section{Dasar Hukum Kebolehan Adanya Dissenting Opinion dalam Putusan Pengadilan di Indonesia}

Keadaan dimana salah satu hakim tidak setuju dengan putusan hakim mayoritas yang ditandai dengan pendapat tertulis.. ${ }^{1}$ Dissenting opinionn ini merupakan cerminan daripada kebebasan hakim untuk menemukan kebenaran materil dalam membuat putusan pengadilan. Makna kebebasan yang terkandung dalam pancasila merupakan kebebasan yang diwarnai dan dijiwai oleh nilai-nilai yang hidup dalam bangsa Indonesia yang telah berakar dalam kepribadian bangsa.

\footnotetext{
${ }^{1}$ Henny Handayani Sirait, "Dissenting Opinion sebagai Bentuk Kebebasan Hakim dalam Membuat Putusan Pengadilan guna Menemukan Kebenaran Materil", Medan: Fakultas Hukum Universitas Sumatera Utara. 2014.
} 
Kedudukan dissenting opinion adalah sebagai yurisprudensi untuk kasus-kasus serupa yang menjadi persoalan perbedaan pendapat, namun itu tidak bisa dijadikan sebagai dasar hukum hanya sebagai referensi. Perbedaan pendapat hakim (dissenting opinion) dari salah satu hakim dimana putusan tersebut belum memiliki kekuatan hukum tetap, maka menjadikan putusan itu harus ditangguhkan sementara, diuji materilnya atau dibatalkan. ${ }^{2}$ Putusan Mahkamah Agung Konstitusi dalam pelaksanaannya terdapat tiga alternatif amar/putusan, diantranya menyatakan tidak diterima (Niet Onvankelijke Verklaard), menolak, dan mengabulkan. Apabila hakim berbeda pendapat dalam melaksanakan putusan, maka hakim yang memilih keputusan minoritas itu yang dimaksud dissenting opinion. ${ }^{3}$

Selain itu, prinsip kebebasan sejalan dengan sila dalam pancasila dan sekaligus merupakan kebebasan yang disertai rasa kesadaran dan tanggung jawab sosial. Nilai kebebasan dalam pancasila lebih mengutamakan kewajiban sosial daripada penuntutan hak pribadi, lebih mengutamakan memadukan pendapat dengan jalan musyawarah daripada menekankan pendapat sendiri terhadap pihak lain, dan mengutamakan nilainilai ketuhanan. ${ }^{4}$ Sebenarnya, dissenting opinion sudah lama dikenal dalam dunia peradilan di Indonesia. Namun, belum dimuatnya dalam putusan pengadilan. Dissenting opinion hanya dicatat pada buku besar pengadilan dan dikelola ketua pengadilan secara rahasia. $^{5}$

Selanjutnya dasar hukum dissenting opinion juga diatur dalam Pasal 28 E ayat (3) diberikan jaminan dalam mengeluarkan pendapat "...berhak atas kebebasan...dan mengeluarkan pendapat." Inilah yang menjadi dasar hakim dalam pengambilan keputusan secara bebas tanpa adanya intervensi dari berbagai pihak guna menegakkan keadilan yang dapat dipertanggungjawabkan.

Konsep kebebasan peradilan tersebut diperoleh pemahaman bahwa kebebasan hakim (independence of judiciary) harus diimbangi dengan pertanggungjawaban peradilan (judicial accountability). Konsep inilah yang melahirkan konsep pertanggungjawaban peradilan (judicial accountability) termasuk di dalamnya integriti dan transparansi, yang dibangun di atas prinsip yang merupakan harmonisasi antara tanggung jawab hukum (legal responsibility) dan tanggungjawab kemasyarakatan (social responsibility). Norma, etika, hokum dan kesadaran pada tuhan yang maha esa, kepada sesame manusia dan bangsa merupakan sandaran dalam membatasi kebebasan itu sendiri.

\footnotetext{
${ }^{2}$ H.F. Abraham Amos, Legal Opinion: Aktualisasi Teoritis Dan Empirisme, (Jakarta: PT. Raja Grafindo Persada, 2004), 1

3 Jimly Asshiddiqie, Hukum Acara Pengujian Undang-Undang, (Jakarta: Sinar Grafika, 2012), 199.

${ }^{4}$ Peter Mahmud Marzuki, Penelitian Hukum (Jakarta: Kencana Prenada Media. 2009), hlm. 132.

5 Artikel, Sumatera Ekspres, (10 maret 2004), 6. Dan lihat pula Mahkamah Agung RI , Pedoman Pelaksanaan Tugas dan Administrasi Pengadilan, Buku II edisi revisi, (Jakarta: Reedbox Publisher diterjemahkan oleh Muhammad Iqbal S.Hi.,MA, 2010), 103.
} 
Sehingga meskipun bebas hakim tidak mengabaikan aspek-aspek tersebut dalam membuat putusan. ${ }^{6}$

Selain itu, hakim dalam menentukan kebenaran materil berdasarkan pada peraturan perundang-undangan di atur dalam Pasal 10 ayat (1) Undang-Undang Nomor 48 Tahun 2009 Jo Pasal 14 ayat (1) Pasal 28 ayat (1) Undang-Undang Nomor 4 Tahun 2004 Jo Undang-Undang Nomor 14 Tahun 1970 jo tentang Kekuasaan Kehakiman. Berdasarkan ketentuan undang-undang itulah, maka lahirlah konsep dissenting opinion, karena pasal di atas jelas dan tegas mengatur bahwa Pengadilan dilarang menolak untuk memeriksa, mengadili, dan memutus suatu perkara yang diajukan dengan dalih bahwa hukum tidak ada atau kurang jelas, melainkan wajib untuk memeriksa dan mengadilinya.

Namun demikian hingga keluarnya Undang-Undang Nomor 48 Tahun 2009 tentang Kekuasaan Kehakiman, barulah pranata dissenting opinion dalam praktek peradilan di Indonesia mempunyai landasan yuridis yang jelas. Walaupun UndangUndang Nomor 48 Tahun 2009 jo Undang-Undang Nomor 4 Tahun 2004 tidak menjelaskan dasar filosofis dari pencantuman pasal 19 ayat 5 ini, namun dapat diduga hal ini erat dengan penjabaran pasal 28 F UUD NRI 1945 dan keinginan para pembuat undangundang untuk membuat para hakim dapat bertanggung jawab secara individual terhadap apa yang menjadi pertimbangan dalam memutus perkara. Hal ini tampak pada pengakuan dua orang anggota Dewan Perwakilan Rakyat (DPR) yang turut membidani lahirnya Undang-Undang Nomor 48 Tahun 2009 Jo Undang-Undang Nomor 4 Tahun 2004 tentang kekuasaan kehakiman. ${ }^{7}$

Kemudian di dalam undang-undang yang sama, yaitu Pasal 14 ayat (2) dan ayat (3) mengatur bahwa, putusan hakim yang berbeda pendapat harus dimuat dalam laporan putusan. Selanjutnya hakim menyampaikan pertimbangan putusan perkara sebagai sesuatu yang tidak terpisahkan. Apabila terjadi perbedaan pendapat maka suara terbanyak diambil dan wajib dicantumkan dalam putusan. sesuai dengan UndangUndang Nomor 5 Tahun 2004 tentang Perubahan Undang-Undang Nomor 14 Tahun 1985 yang telah disahkan DPR-RI bulan Desember 2003, mencantumkan pasal 19 yang menegaskan bahwa:

Ayat 4: Dalam sidang permusyawaratan, setiap hakim wajib menyampaikan pertimbangan atau pendapat tertulis terhadap perkara yang sedang diperiksa dan menjadi bagian yang tak terpisahkan dari putusan.

Ayat 5: Dalam hal sidang permusyawaratan tidak dapat dicapai kata mufakat bulat, pendapat hakim yang berbeda wajib dimuat dalam putusan. ${ }^{8}$

\footnotetext{
${ }^{6}$ Henny Handayani Sirait, "Dissenting Opinion sebagai Bentuk Kebebasan Hakim dalam Membuat Putusan Pengadilan guna Menemukan Kebenaran Materil", Medan: Fakultas Hukum Universitas Sumatera Utara. 2014.

${ }^{7}$ Rifqi Assegaf dan Josi Khatarina, Membuka Ketertutupan Peradilan (Jakarta: LeilP, 2005), 35.

${ }^{8}$ Lihat Pasal 19 Undang-Undang Nomor 5 Tahun 2004 tentang Perubahan Undang-Undang Nomor 14 Tahun 1985
} 
Dissenting opinion biasanya dimuat dalam bagian akhir putusan setelah putusan mayoritas. Tujuan dissenting opinion untuk menjelaskan bahwa putusan hakim transparan dan memberikan akuntabilitas kepada masyarakat.

Perspektif terakhir yakni kebebasan hakim dalam menemukan kebenaran materil melalui musyawarah majelis hakim. Bentuk implementasi dari kebebasan hakim ialah kebebasan dalam melakukan penemuan hukum secara aktif. Penemuan kebenaran ini sebagai salah satu bentuk penerapan peraturan perundang-undangan dan hukum yang hidup di masyarakat.

Hakim menggunakan berbagai pendekatan dalam putusan setelah pemeriksaan dinyatakan ditutup, di antaranya pendekatan keseimbangan/keadilan, pendekatan seni dan intuisi, pendekatan keilmuan, pendekatan pengalaman, dan pendekatan kebijaksanaan seorang hakim. Menurut Mackenzie, terdapat beberapa teori diantaranya teori keseimbangan, teori pendekatan seni dan intuisi, teori ratio decidendi, teori pendekatan keilmuan, teori pendekatan pengalaman, teori kebijaksaaan. ${ }^{9}$

Sedangkakan Shidarta, ${ }_{1}^{10}$ menyatakan bahwa terdapat enam langkah dalam proses penalaran hukum putusan hakim, yaitu:

Pertama, mengidentifikasi fakta-fakta untuk menghasilkan suatu struktur kasus yang sungguh-sungguh diyakini oleh hakim sebagai kasus yang riil terjadi; Kedua, menghubungkan struktur kasus tersebut dengan sumber hukum yang relevan sehingga ia dapat menetapkan perbuatan hukum dalam peristilahan yuridis; Ketiga, menyeleksi sumber hukum dan aturan hukum yang relevan untuk kemudian mencari tahu kebijakan yang terkandung didalam aturan hukum itu (the policies underlying those rule), sehingga dihasilkan struktur aturan yang koheren. Keempat, menghubungan struktur aturan dengan struktur kasus. Kelima, mencari alternatif penyelesaian yang mungkin. Keenam, menetapkan pilihan atas salah satu alternatif untuk kemudian diformulasikan sebagai putusan akhir.

Berdasarkan pemaparan di atas bahwa, yang menjadi dasar hukum kebolehan adanya dissenting opinion dalam putusan pengadilan di Indonesia, yaitu Pasal 1 ayat (3), Pasal 24, Pasal 28 E ayat (2) dan ayat (3) Undang-Undang Dasar Tahun 1945. Selain itu, diatur juga oleh Pasal 10 ayat (1), Pasal 14 ayat (2) dan ayat (3) Undang-Undang Nomor 48 Tahun 2009 tentang Kekuasaan Kehakiman. Adapun aturan mengenai kebolehan dissenting opinion dalam Undang-Undang tentang Kekuasaan Kehakiman selaras dengan peraturan yang di atasnya, yakni Undang-Undang Dasar 1945. Kebebasan personal hakim melalui jalan musyawarah majelis hakim merupakan cerminan kepribadian Indonesia sesuai sila ke-4 Pancasila. Musyawarah majelis hakim untuk menuju mufakat

\footnotetext{
${ }^{9}$ Moelyatno, Asas-Asas Hukum Pidana, (dalam) Ahmad Rifai, Penemuan Hukum Oelh hakiam dalan Persfektif Hukum Progresif, (Jakarta: Sinar Grafika, 2011), 102-113.

${ }^{10}$ Shidarta, Karakteristik Penalaran Hukum dalam konteks Kelndonesiaan, (dalam) M.Syamsudin, Konstruksi Baru Budaya Hukum Hakim Berbasis Hukum Progresif, (Jakarta: Kencana Prenada Media Group, 2012), 87.
} 
terjadi jika adanya perbedaaan di antara para hakim. Perbedaan yang dimaksud dalam musyawarah majelis hakim adalah perbedaan pendapat terkait permasalahan hukum yang sedang diperiksa, bukan perbedaan terkait kedudukan antar hakim yang memeriksa perkara yang sama.

\section{Argumen Hukum Dissenting Opinion Majelis Hakim pada Putusan Nomor: 579/K/AG/2010 Tentang Penyelesaian Sengketa Waris Bagi Ahli Waris Pengganti}

Adapun model struktur isi anotasi putusan, sekurang-kurangnya harus memuat isi sebagai berikut: 1) identitas perkara; 2) kasus posisi; 3) fakta hukum; 4) pertimbangan hukum dan amar putusan; 5) masalah hukum; 6) anotasi/analisis; dan 7) konklusi dan penemuan hukum. Putusan Nomor: 579/ K/AG/2010 ini membahas mengenai sengketa waris yang melibatkan Rogayah binti Ahmad, Maimunah binti Ahmad, dan Nurbayah binti Ahmad sebagai Pemohon Kasasi dahulu Tergugat I, III dan IV/Para Pembanding melawan M. Soleh bin Abdul Hamiddan kawan-kawan sebagai Termohon Kasasi dahulu Para Penggugatdan Tergugat II.

Putusan di atas, dilatarbelakangi peristiwa hukum yang dijadikan dasar gugatan dalam perkara gugatan waris yaitu: 1) Ahmad bin Sa'i menikah dengan Salimah binti Soleh tahun 1919 dan Ahmad bin Sa'i telah meninggal dunia pada tanggal 10 Januari 1993, karena sakit dikebumikan di Sekayu dan isterinya Salimah binti Soleh telah meninggal dunia pada tanggal 20 Februari 1982, karena sakit dan dikebumikan di Sekayu; 2) Orang tua almarhum Ahmad bin Sa'i dan orang tua almarhumah Salimah binti Soleh telah meninggal dunia terlebih dahulu dari almarhum Ahmad bin Sa'i dan almarhumah Salimah binti Soleh; 3) Almarhum Ahmad bin Sa'i dan almarhumah Salimah binti Soleh selama pernikahan tidak pernah bercerai; dan 4) Almarhum Ahmad bin Sa'i dan almarhumah Salimah binti Soleh semasa hidupnya mempunyai keturunan sebagai berikut:

1. Abdullah bin Ahmad meninggal dunia pada tahun 1974 dan meninggalkan ahli waris pengganti: 1) Lukman Hakim bin Abdullah; 2) A. Muslim bin Abdullah; 3) $\mathrm{Hj}$. Siti Hawa binti Abdullah; 4) Husnah binti Abdullah; 5) Azizah binti Abdullah; 6) Abu Sopian bin Abdullah; dan 7) Rustam bin Abdullah.

2. Hj. Maimunah binti Ahmad.

3. Abdul Hamid bin Ahmad, meninggal dunia pada tahun 1986 dan meninggalkan ahli waris pengganti: 1) Maria Ulpa binti Abdul Hamid; 2) Utami binti Abdul Hamid; 3) Sulastri binti Abdul Hamid; 4) M. Soleh, S.E. bin Abdul Hamid; 5) Faridah binti Abdul Hamid; 6) Zaleha binti Abdul Hamid; dan 7) Muhammad Usman bin Abdul Hamid.

4. Anwar bin Ahmad, meninggal dunia pada tahun 1962 dan meninggalkan ahli waris pengganti Lisheri binti Anwar.

5. Arbain bin Ahmad. 
6. Rogayah binti Ahmad, dan

7. Nurbayah binti Ahmad.

Almarhum Ahmad bin Sa'i dan almarhumah Salimah binti Soleh juga meninggalkan harta warisan berupa Satu bidang tanah pekarangan yang berukuran panjang 33,70 $\mathrm{m}$ dan lebar $15,40 \mathrm{~m}$ diatas tanah tersebut berdiri 1 (satu) unit rumah panggung berukuran panjang $26 \mathrm{~m}$, lebar $6,50 \mathrm{~m}$, atap genteng dinding papan lantai papan terletak di Jalan Merdeka RT.05, RW.02, Kelurahan Soak Baru, Kecamatan Sekayu, Kabupaten Musi Banyuasin, dengan batas-batas sebagai berikut: 1) Sebelah barat berbatasan dengan Jalan Merdeka Sekayu; 2) Sebelah timur berbatasan dengan tanah milik Lukman Hakim Abdullah; 3) Sebelah utara berbatasan dengan tanah milik H. Yazid bin Suud (Alm.); dan 4) Sebelah selatan berbatasan dengan tanah milik Halim bin Jahudin dan tanah milik Arbi bin Nuri.

Harta warisan almarhum Ahmad bin Sa'i dan almarhumah Salimah binti Soleh tersebut diatas belum pernah dibagikan kepada ahli waris yang berhak menerimanya baik secara Hukum Islam maupun secara Hukum Adat; Harta warisan tersebut diatas dikuasai oleh Rogaya binti Ahmad Tergugat I dengan dalih dapat membeli dari Arbain bin Ahmad Tergugat II, Hj . Maimunah binti Ahmad Tergugat III dan Nurbaya binti Ahmad Tergugat IV, dan kesepakatan jual beli tersebut tanpa sepengetahuan dari para Penggugat yang juga ahli waris dari almarhum Ahmad bin Sa'i dan almarhumah Salimah binti Soleh.

Pihak Penggugat telah berulang kali melakukan perdamaian kepada pihak Tergugat dengan jalan musyawarah dan mufakat baik melalui pemerintah setempat maupun melalui jalur kekeluargaan namun tidak berhasil, bahkan pernah juga para Penggugat melakukan sanggahan kepada Bapak Camat Sekayu sekiranya surat jual beli dan pengakuan hak No.593/134/11/2008 tanggal 22 Februari 2008 yang diajukan oleh Tergugat dibatalkan karena objek sengketa tersebut adalah harta warisan almarhum Ahmad bin Sa'i dan almarhumah Salimah binti Soleh yang belum dibagikan kepada ahli waris yang lainnya.

Berdasarkan dasar gugatan diatas, Para Penggugat memohon kepada Pengadilan Agama Sekayu agar: 1) Menerima dan mengabulkan gugatan Penggugat; 2) Menetapkan ahli waris yang tersebut pada poin 1 s.d. poin 7; 3) Menetapkan harta seperti pada tersebut diatas adalah sebagai harta waris almarhum Ahmad bin Sa'i dan almarhumah Salimah binti Soleh yang dapat dibagikan kepada ahli waris yang berhak menerimanya; 4) Menetapkan kadar bagian yang harus diterima masing-masing ahli waris sesuai Hukum Islam (Fiqh Faro'id); 5) Menghukum Tergugat untuk menyerahkan harta peninggalan almarhum Ahmad bin Sa'i dan almarhumah Salimah binti Soleh yang dikuasai oleh Tergugat untuk dibagikan kepada ahli waris yang berhak sesuai kadar bagian masing-masing; dan 6) Menetapkan biaya perkara menurut aturan yang berlaku. 
Selanjutnya, terhadap gugatan tersebut, Tergugat I, III, dan IV mengajukan eksepsi yang pada pokoknya atas dalil-dalil sebagai berikut:

Pertama, Bahwa almarhum orang tua kami (Ahmad bin Sa'i dan Salimah binti Soleh) mempunyai anak sebagai ahli waris dan mempunyai cukup banyak harta peninggalannya.

Kedua, Bahwa secara resmi harta peninggalan almarhum orang tua kami, belum pernah dibagikan atau pun diberikan kepada kami anak-anaknya sebagai ahli waris maupun kepada cucunya.

Ketiga, Bahwa almarhum orang tua kami tidak saja meninggalkan sebidang tanah pekarangan berikut di atasnya berdiri sebuah rumah panggung tua yang terletak di Jalan Merdeka RT.05, RW.02, Kelurahan Soak Baru, Kecamatan Sekayu, akan tetapi masih banyak lagi peninggalan lainnya berupa kebun buah, kebun karet, tanah kosong/belukar yang terletak di Sekayu maupun Talang Piase dan lain-lain.

Keempat, Bahwa lebih kurang awal tahun 1994, kami ahli waris telah bermusyawarah akan menjual sebuah panggung tua berikut sebidang tanah pekarangannya yang terletak di Jalan Merdeka RT.05, RW.02, Kelurahan Soak Baru, Kecamatan Sekayu kepada para ahli waris maupun cucu almarhum orang tua kami, termasuk telah pernah diberitahukan dan di tawarkan kepada saudara keponakan kami M. Soleh, S.E. bin Abdul Hamid supaya berkenan membelinya. Namun pada waktu itu, tidak ada satupun anak maupun cucu almarhum orang tua kami yang mau membeli rumah tersebut. Kemudian setelah beberapa kali dimusyawarahkan, disepakati agar rumah tersebut jangan diperjualbelikan kepada orang lain selain anak maupun cucu almarhum orang tua kami. Sehingga akhirnya berdasarkan musyawarah dan disepakati secara kekeluargaan, bahkan rumah tersebut akan dijual dan diberikan kepada saudara kami Rogayah binti Ahmad. Selanjutnya setelah semuanya disepakati dan diselesaikan, maka jual belinya secara resmi baru dibuatkan "Surat pernyataan Jual Beli" pada tanggal 17 Januari 1995 yang dituangkan diatas Kertas Segel Tahun 1994 yang ditandatangani oleh cucu-cucu almarhum orang tua kami.

Beradasarkan musyawarah dan kesepakatan secara kekeluargaan tersebut, maka jual beli sebuah rumah panggung tua berikut sebidang tanah pekarangannya sebagaimana tersebut diatas adalah sah menurut hukum dan legal formalnya telah dibuatkan "Surat Pengakuan Hak dan Surat Keterangan" berdasarkan atas hak surat pernyataan jual beli diatas segel yang telah ditandatangani dan diketahui oleh semua pihak yang terkait dan oleh aparat pemerintah yang berwenang (Lurah dan Camat). Oleh karena itu, kami selaku Tergugat menolak anggapan yang menyatakan bahwa jual beli rumah tersebut tanpa musyawarah dan tanpa kesepakatan serta tanpa sepengetahuan para ahli waris dan cucu-cucu almarhum orang tua kami. 
Di dalam perkara tersebut, peneliti menemukan beberapa fakta hukum yang dapat dijadikan bahan pertimbangan atas penyelesaian perkara tersebut, diantaranya ialah:

1. Ahmad bin Sa'i menikah dengan Salimah binti Soleh tahun 1919 dan Ahmad bin Sa'i telah meninggal dunia pada tanggal 10 Januari 1993, karena sakit dikebumikan di Sekayu dan isterinya Salimah binti Soleh telah meninggal dunia pada tanggal 20 Februari 1982;

2. Almarhum Ahmad bin Sa'i dan almarhumah Salimah binti Soleh semasa hidupnya mempunyai keturunan sebagai berikut:

a. Abdullah bin Ahmad meninggal dunia pada tahun 1974 dan meninggalkan ahli waris pengganti:

1) Lukman Hakim bin Abdullah;

2) A. Muslim bin Abdullah;

3) $\mathrm{Hj}$. Siti Hawa binti Abdullah;

4) Husnah binti Abdullah;

5) Azizah binti Abdullah;

6) Abu Sopian bin Abdullah;

7) Rustam bin Abdullah;

b. Hj . Maimunah binti Ahmad;

c. Abdul Hamid bin Ahmad, meninggal dunia pada tahun 1986 dan meninggalkan ahli waris pengganti:

1) Maria Ulpa binti Abdul Hamid;

2) Utami binti Abdul Hamid;

3) Sulastri binti Abdul Hamid;

4) M. Soleh, S.E. bin Abdul Hamid;

5) Faridah binti Abdul Hamid;

6) Zaleha binti Abdul Hamid;

7) Muhammad Usman bin Abdul Hamid;

d. Anwar bin Ahmad, meninggal dunia pada tahun 1962 dan meninggalkan ahli waris pengganti Lisheri binti Anwar;

e. Arbain bin Ahmad;

f. Rogayah binti Ahmad;

g. Nurbayah binti Ahmad;

3. Almarhum Ahmad bin Sa'i dan almarhumah Salimah binti Soleh meninggalkan harta warisan berupa Satu bidang tanah pekarangan yang berukuran panjang 33,70 $\mathrm{m}$ dan lebar $15,40 \mathrm{~m}$ diatas tanah tersebut berdiri 1 (satu) unit rumah panggung berukuran panjang $26 \mathrm{~m}$, lebar 6,50 $\mathrm{m}$, atap genteng dinding papan lantai papan terletak di Jalan Merdeka RT.05, RW.02, Kelurahan Soak Baru, Kecamatan Sekayu, Kabupaten Musi Banyuasin. 
4. Harta warisan almarhum Ahmad bin Sa'i dan almarhumah Salimah binti Soleh tersebut belum pernah dibagikan kepada ahli waris yang berhak menerimanya baik secara Hukum Islam maupun secara Hukum Adat.

5. Harta warisan tersebut diatas dikuasai oleh Rogaya binti Ahmad Tergugat I.

Bahwa terhadap gugatan tersebut Pengadilan Agama Sekayu telah mengambil putusan, yaitu putusan Nomor: 212/Pdt.G/2008/PA.Sky tanggal 24 Februari 2009 M., bertepatan dengan tanggal 28 Shafar $1430 \mathrm{H} .$, yang amarnya sebagai berikut:

Dalam Eksepsi: Menyatakan Eksepsi dari Terguga I, III dan IV dikabulkan untuk sebagian dan ditolak untuk selain dan selebihnya;

Dalam Pokok Perkara:

1. Menerima dan mengabulkan gugatan para Penggugat;

2. Menetapkan bahwa ahli waris dari almarhum Ahmad bin Sa'i adalah:

a. Rogayah binti Ahmad (anak perempuan);

b. Arbain bin Ahmad (anak laki-laki);

c. Hj. Maimunah binti Ahmad (anak perempuan);

d. Nurbayah binti Ahmad (anak perempuan);

e. M. Soleh, S.E. bin Abdul Hamid (cucu laki-laki);

f. Maria Ulpa binti Abdul Hamid (cucuperempuan);

g. Utami binti Abdul Hamid (cucuperempuan);

h. Sulastri binti Abdul Hamid (cucuperempuan);

i. Faridah binti Abdul Hamid (cucuperempuan);

j. Zaleha binti Abdul Hamid (cucuperempuan);

k. Muhammad Usman bin Abdul Hamid (cucu laki-laki);

I. A.Muslim bin Abdullah (cucu laki-laki);

m. Hj . Siti Hawa binti Abdullah (cucuperempuan);

n. Azizah binti Abdullah (cucuperempuan);

o. Abu Sopian bin Abdullah (cucu laki-laki);

p. Rustam bin Abdullah (cucu laki-laki );

q. Lukman Hakim bin Abdullah (cucu laki-laki);

r. Husnah binti Abdullah (cucuperempuan);

s. Lisheri binti Anwar (cucuperempuan);

3. Menetapkan harta yang berupa sebidang tanah yang berukuran 33,70 $\mathrm{m} \times 15,40 \mathrm{~m}$ dan diatasnya berdiri bangunan sebuah rumah panggung berukuran $26 \mathrm{~m} \times 6,50 \mathrm{~m}$ yang terletak di Jalan Merdeka, RT.05, RW.02, Kelurahan Soak Baru, Kecamatan Sekayu, Kabupaten Musi Banyuasin sebagai harta waris almarhum Ahmad bin Sa'i dengan batas-batas sebagai berikut:

a. Sebelah barat berbatasan dengan Jalan Merdeka Sekayu;

b. Sebelah timur berbatasan dengan tanah milik Lukman Hakim Abdullah;

c. Sebelah utara berbatasan dengan tanah milik H. Yazid bin Suud (Alm.); 
d. Sebelah selatan berbatasan dengan tanah milik Halim bin Jahudin dan tanah milik Arbi bin Nuri;

4. Menetapkan kadar bagian untuk masing-masing ahli waris adalah sebagai berikut:

a. Rogayah binti Ahmad (anak perempuan) mendapat 1/11 bagian;

b. Arbain bin Ahmad (anak laki-laki) mendapat 2/11 bagian;

c. $\mathrm{Hj}$. Maimunah binti Ahmad (anak perempuan) mendapat 1/11 bagian;

d. Nurbayah binti Ahmad (anak perempuan) mendapat 1/11 bagian;

e. M. Soleh, S.E. bin Abdul Hamid (cucu laki-laki) mendapat 4/99 bagian;

f. Maria Ulpa binti Abdul Hamid (cucu perempuan) mendapat 2/99 bagian;

g. Utami binti Abdul Hamid (cucu perempuan) mendapat 2/99 bagian;

h. Sulastri binti Abdul Hamid (cucu perempuan) mendapat 2/99 bagian;

i. Faridah binti Abdul Hamid (cucu perempuan) mendapat 2/99 bagian;

j. Zaleha binti Abdul Hamid (cucu perempuan) mendapat 2/99 bagian;

k. Muhammad Usman bin Abdul Hamid (cucu laki-laki) mendapat 4/99;

I. A.Muslim bin Abdullah (cucu laki-laki) mendapat 4/121 bagian;

m. Hj. Siti Hawa binti Abdullah (cucu perempuan) mendapat 2/121 bagian;

n. Azizah binti Abdullah (cucu perempuan) mendapat 2/121 bagian;

o. Abu Sopian bin Abdullah (cucu laki-laki) mendapat 4/121 bagian;

p. Rustam bin Abdullah (cucu laki-laki) mendapat 4/121 bagian;

q. Lukman Hakim bin Abdullah (cucu laki-laki) mendapat 4/121 bagian;

r. Husnah binti Abdullah (cucu perempuan) mendapat 2/121 bagian;

s. Lisheri binti Anwar (cucu perempuan) mendapat 2/121 bagian;

5. Menghukum Tergugat I untuk menyerahkan harta warisan yang tersebut pada diktum 3 diatas kepada para ahli waris almarhum Ahmad bin Sa'i untuk dibagi menurut kadarnya masing-masing, atau apabila tidak dapat dibagi secara natura, maka harta tersebut untuk di jual lelang didepan pejabat yang berwenang, dan hasilnya yang dibagi kepada masing-masing ahli waris tersebut.

6. Membebankan biaya perkara kepada para Penggugat dan Para Terggugat secara tanggung renteng yang hingga kini berjumlah Rp. 956.000,- (sembilan ratus lima puluh enam ribu rupiah).

Selanjutnya pada tingkat banding, putusan pada tingkat pertama tersebut telah diperbaiki amarnya yang mengenai besarnya bagian ahli waris dengan putusan Nomor: og/Pdt.G/2009/PTA.Plg tanggal 10 Desember 2009 M., yang bertepatan dengan tanggal 23 Dzulhijah1430 H., yang perbaikan amarnya sebagai berikut: Menetapkan bagian masing- masing ahli waris almarhum Ahmad bin Sa'i adalah sebagai berikut:

1. Rogayah binti Ahmad (anak perempuan) mendapat $1 / 8=99 / 792$ bagian;

2. Arbain bin Ahmad (anak laki-laki) mendapat 2/8=198/792 bagian;

3. Hj . Maimunah binti Ahmad (anak perempuan) mendapat $1 / 8=99 / 792$ bagian;

4. Nurbayah binti Ahmad (anak perempuan) mendapat $1 / 8=99 / 792$ bagian; 
5. M. Soleh, S.E. bin Abdul Hamid (cucu laki-laki) mendapat $2 / 9 \times 1 / 8=2 / 72=22 / 792$ bagian;

6. Maria Ulpa binti Abdul Hamid (cucu perempuan) mendapat $1 / 9 \times 1 / 8=2 / 72=11 / 792$ bagian;

7. Utami binti Abdul Hamid (cucu perempuan) mendapat $1 / 9 \times 1 / 8=2 / 72=11 / 792$ bagian;

8. Sulastri binti Abdul Hamid (cucu perempuan) mendapat $1 / 9 \times 1 / 8=2 / 72=11 / 792$ bagian;

9. Faridah binti Abdul Hamid (cucu perempuan) mendapat $1 / 9 \times 1 / 8=2 / 72=11 / 792$ bagian;

10. Zaleha binti Abdul Hamid (cucu perempuan) mendapat $1 / 9 \times 1 / 8=2 / 72=11 / 792$ bagian;

11. Muhammad Usman bin Abdul Hamid (cucu laki-laki) mendapat 2/9x1/8= 2/72=22/792 bagian;

12. A. Muslim bin Abdullah (cucu laki-laki) mendapat $2 / 11 \times 1 / 8=2 / 88=18 / 792$ bagian;

13. Hj. Siti Hawa binti Abdullah (cucu perempuan) mendapat $1 / 11 \times 1 / 8=1 / 88=9 / 792$ bagian;

14. Azizah binti Abdullah (cucu perempuan) mendapat $1 / 11 \times 1 / 8=1 / 88=9 / 792$ bagian;

15. Abu Sopian bin Abdullah (cucu laki-laki) mendapat $2 / 11 \times 1 / 8=2 / 88=18 / 792$ bagian;

16. Rustam bin Abdullah (cucu laki-laki) mendapat $2 / 11 \times 1 / 8=2 / 88=18 / 792$ bagian;

17. Lukman Hakim bin Abdullah (cucu laki-laki) mendapat $2 / 11 \times 1 / 8=2 / 88=18 / 792$ bagian;

18. Husnah binti Abdullah (cucu perempuan) mendapat $1 / 11 \times 1 / 8=1 / 88=9 / 792$ bagian;

19. Lisheri binti Anwar (cucu perempuan) mendapat 1/8=99/792 bagian;

Kemudian pada tingkat kasasi, Mahkamah Agung memberikan amar yang menolak permohonan kasasi dari para Pemohon Kasasi (Rogayah binti Ahmad, $\mathrm{Hj}$. Maimunah binti Ahmad, Nurbayahbinti Ahmad) dan membebankan biaya kepada Para Pemohon Kasasi/ Tergugat I, III dan IVsebesar Rp. 500.000,- (lima ratus ribu rupiah).

Adapun yang menjadi pert imbangan Mahkamah Agung dalam Putusan Nomor: 579 K/AG/ 2010 antara lain:

Menimbang, bahwa mengenai alasan ke-1 sampai dengan ke-3 Bahwa alasan tersebut tidak dapat dibenarkan, karena Judex Facti tidak salah menerapkan hokum. Menimbang, bahwa dalam sidang musyawarah Majelis Hakim Agung di Mahkamah Agung RI, terjadi adanya perdapat yang berbeda dari Hakim Agung Drs. $\mathrm{H}$. Habiburrahman, M.Hum., yang berpendapat sebagai berikut:

Menimbang, bahwa gugatan tidak dapat diterima, para pihak bukan pihak, karena ahli waris pengganti baru ada pada tahun 1991, sejak diberlakukannya Kompilasi Hukum Islam yang dalam Pasal 185 mengatur adanya ahli waris pengganti. 
Menimbang, bahwa sekalipun ada dua pendapat yang berbeda tersebut (dissenting opinion) tentang perihal akibat hukumnya, namun demi terciptanya rasa keadilan dan ketentraman keduanya, maka permohonan kasasi yang diajukan oleh para Pemohon Kasasi (Rogayah binti Ahmad, Hj. Maimunah binti Ahmad, dan Nurbayah binti Ahmad) tersebut harus ditolak.

Menimbang, bahwa oleh karena permohonan kasasi dari para Pemohon Kasasi ditolak, maka para Pemohon Kasasi dihukum untuk membayar biaya perkara dalam tingkat kasasi ini.

Namun demikian peneliti berpendapat bahwa ada persoalan hukum yang ada dalam perkara ini cukup menarik untuk dianalisis, karena kedudukan para pihak yang mengajukan perkara gugatan adalah berkedudukan sebagai ahli waris pengganti dari ahli warisnya yang telah meninggal dunia sebelum adanya ketentuan mengenai ahli waris pengganti yang baru ada pada tahun 1991, sejak diberlakukannya Kompilasi Hukum Islam yang dalam Pasal 185 mengatur adanya ahli waris pengganti.

Implikasinya, pada tingkat kasasi melalui putusan Mahkamah Agung RI terdapat perbedaan pendapat antara ketua majelis hakim dengan hakim anggota yang mana perbedaan pendapat (dissenting opinion) tersebut mengenai kedudukan hukumpara pihak (legal standing) yang berhak mengajukan perkara. Namun pada akhirnya kedudukan hukum Para Penggugat yang berperkara pada tingkat pertama sebagai ahli waris pengganti mempunyai kedudukan hukum untuk mengajukan perkara gugatan waris tersebut.

Dalil hukum yang ditampilkan sebagai bagian dari adanya dasar gugatan yang diajukan oleh Para Penggugat adalah bahwa Pewaris yaitu Ahmad bin Sa'i meninggal pada tanggal 10 Januari 1993 dan isterinya Salimah binti Soleh meninggal pada tanggal 20 Februari 1982, selain itu, ayah ahli waris pengganti Abdullah bin Ahmad meninggal pada tahun 1974 dan Abdul Hamid bin Ahmad meninggal pada tahun 1986, meninggalnya mereka sebelum berlakunya Undang-Undang Nomor 7 Tahun 1989 dan sebelum keluarnya Intruksi Presiden (Inpres) Nomor 1 Tahun 1991 serta Keputusan Menteri Agama Nomor 154 Tahun 1991 Tentang Kompilasi Hukum Islam. Oleh karenanya, dalam hukum kewarisan dari almarhum dan almarhumah lebih didasarkan pada asas berlakunya suatu Undang-Undang (Asas Legalitas), sehingga terhadapnya tidak bisa berlaku ketentuan pasal 185 Kompilasi Hukum Islam.

Asas legalitas adalah istilah dalam hukum modern yang dipinjam oleh hukum Islam karena kesamaan prinsip dengan itu. Dalam hukum Islam pengertian asal legalitas adalah suatu prinsip di mana suatu perbuatan hukum baru dianggap dapat melanggar hukum jika waktu peristiwa itu terjadi sudah ada peraturan yang melarang. Prinsip hukum tidak berlaku surut dalam kajian hukum Islam, dalam perkembangannya diberlakukan pula perundang-undangan, terutama di negara-negara yang bukan hanya 
menerapkan hukum Islam tetapi menerapkan pula hukum-hukum lain. Atas dasar ini dalam sidang musyawarah Majelis Hakim Agung di Mahkamah Agung RI Habiburrahman sebagai Ketua Majelis keberatan terhadap putusan Tingkat Pertama dan Tingkat Banding yang seharusnya gugatan para Penggugat tidak dapat diterima karena kedudukan Para Penggugat hanya sebatas ahli waris pengganti bukan merupakan para pihak yang memiliki kedudukan Hukum (legal standing) yang kuat untuk berperkara, dikarenakan ketentuan mengenai ahli waris pengganti baru ada pada tahun 1991, sejak diberlakukannya Kompilasi Hukum Islam yang dalam Pasal 185 mengatur adanya ahli waris pengganti sedangkan ayah mereka (ahli waris pengganti) meninggal pada tahun 1974 dan tahun 1986.

Demikian pula dengan konsep ahli waris Pengganti, meskipun sudah lama muncul dalam pemikiran seperti yang pernak dikemukakan oleh Hazairin, tetapi sebelum munculnya Kompilasi Hukum Islam, pemikiran itu masih belum dianggap "Islam". Kompilasi Hukum Islam itulah yang "mengislamkan" konsep ahli waris pengganti. Karena sebelumnya yang berlaku dikalangan umat Islam adalah bahwa untuk dapat mewarisi disyaratkan ahli waris itu jelas masih hidup ketika pewaris meninggal dunia. Misalkan dalam perkara ini, Abdullah bin Ahmad meninggal pada tahun 1974 dan Abdul Hamid bin Ahmad meninggal pada tahun 1986, maka tidak sah mendapatkan waris dari Pewaris Ahmad bin Sa'i yang meninggal pada tanggal 10 Januari 1993. Berbeda dengan setelah dikeluarkan dan diberlakuknannya Kompilasi Hukum Islam, Abdullah bin Ahmad meninggal pada tahun 1974 dan Abdul Hamid bin Ahmad meninggal pada tahun 1986 tetap sah mendapatkan waris dari Pewaris Ahmad bin Sa'i yang meninggal pada tanggal 10 Januari 1993 tetapi bagian harta warisnya diberikan kepada keturunnanya (anaknnya) karena anaknya berkedudukan sebagai ahli waris pengganti.

Dengan demikian peneliti dapat merumuskan bahwa meskipun dalam musyawarah majelis hakim tingkat kasasi tersebut ada dua pendapat yang berbeda (dissenting opinion) tentang perihal akibat hukumnya, namun demi terciptanya rasa keadilan dan ketentraman keduanya. Putusan majelis hakim kasasi mengenai ahli waris pengganti yang dianggap memiliki legal standing oleh majelis hakim pada Pengadilan Tingkat Pertama dan Tingkat Banding telah tepat dalam dapat memberikan putusan yang adil karena tidak bertentangan dengan Undang-undang yang berlaku. Oleh karena itu permohonan kasasi yang telah diajukan oleh para Pemohon Kasasi (Rogayah binti Ahmad, Hj. Maimunahbinti Ahmad, dan Nurbayah binti Ahmad) tersebut sudah benar dan harus ditolak oleh Majelis Hakim Kasasi.

\section{Kesimpulan}

Dasar hukum kebolehan adanya dissenting opinion dalam putusan pengadilan di Indonesia, yaitu Pasal 182 ayat (5) KUHAP bahwa "dalam musyawarah tersebut, hakim ketua majelis dapat mengajukan pertanyaan dimulai dari hakim yang termuda sampai 
hakim yang tertua, sedangkan yang terakhir mengemukakan pendapatnya adalah hakim ketua majelis dan semua pendapat harus disertai pertimbangan dan alasannya". Selanjutnya dalam Pasal 1 ayat (3), Pasal 24, Pasal 28 E ayat (2) dan ayat (3) UndangUndang Dasar Tahun 1945. Selain itu, diatur juga oleh Pasal 10 ayat (1), Pasal 14 ayat (2) dan ayat (3) Undang-Undang Nomor 48 Tahun 2009 tentang Kekuasaan Kehakiman.

Dasar atau pertimbangan hukum majelis hakim kasasi mengenai menolak permohonan kasasi para ahli waris pengganti yang dianggap memiliki legal standing oleh majelis hakim pada Pengadilan Tingkat Pertama dan Tingkat Banding telah tepat dalam dapat memberikan putusan yang adil karena tidak bertentangan dengan UndangUndang yang berlaku. Pertimbangan utamanya adalah gugatan tidak dapat diterima, yang mana para pihak pemohonan kasasi bukan para pihak ahli waris yang sebenarnya, karena ahli waris pengganti baru ada pada tahun 1991, sejak diberlakukannya Kompilasi Hukum Islam yang dalam Pasal 185 mengatur adanya ahli waris pengganti. Oleh karena itu permohonan kasasi yang telah diajukan oleh para Pemohon Kasasi (Rogayah binti Ahmad, Hj. Maimunahbinti Ahmad, dan Nurbayah binti Ahmad) tersebut sudah benar dan harus ditolak oleh Majelis Hakim Kasasi.

\section{DAFTAR PUSTAKA}

Amos, H.F. Abraham. Legal Opinion: Aktualisasi Teoritis Dan Empirisme, Jakarta: PT. Raja Grafindo Persada. 2004.

Assegaf, Rifqi dan Khatarina, Josi, Membuka Ketertutupan Peradilan Jakarta: LeilP. 2005. Asshiddiqie, Jimly. Hukum Acara Pengujian Undang-Undang. Jakarta: Sinar Grafika. 2012. Iqbal, Muhammad, Sumatera Ekspres, (10 maret 2004), 6. Dan lihat pula Mahkamah Agung RI, Pedoman Pelaksanaan Tugas dan Administrasi Pengadilan, Buku II edisi revisi. Jakarta: Reedbox Publisher, 2010.

Marzuki, Peter Mahmud, Penelitian Hukum, Jakarta: Kencana Prenada Media. 2009.

Moelyatno. Asas-Asas Hukum Pidana, (dalam) Ahmad Rifai, Penemuan Hukum Oelh hakiam dalan Persfektif Hukum Progresif. Jakarta: Sinar Grafika. 2011.

Shidarta, Karakteristik Penalaran Hukum dalam konteks Kelndonesiaan, (dalam) M.Syamsudin, Konstruksi Baru Budaya Hukum Hakim Berbasis Hukum Progresif. Jakarta: Kencana Prenada Media Group. 2012.

Sirait, Henny Handayani. Dissenting Opinion sebagai Bentuk Kebebasan Hakim dalam Membuat Putusan Pengadilan guna Menemukan Kebenaran Materil. Medan: Fakultas Hukum Universitas Sumatera Utara. 2014.

Undang-Undang Nomor 5 Tahun 2004 tentang Perubahan Undang-Undang Nomor 14 Tahun 1985 


\begin{abstract}
Asy-Syari'ah (P-ISSN : 2086-9029 E-ISSN: 2654-5675) is a periodical scientific journal that publishes various results of studies and research, literature review, and other scientific works whose scope covers the field of Islamic law/sharia, law and society in monodisciplinary, interdisciplinary, and multidisciplinary manners. The journal aims to expand and create innovative concepts, theories, paradigms, perspectives and methodologies in the above said scope. The Journal is published twice a year (june and december) by Faculty of Shariah and Law, Sunan Gunung Djati State Islamic University Bandung in collaboration with Asosiasi Sarjana Syariah Indonesia (ASSYI).
\end{abstract}

\title{
EDITORIAL OFFICE:
}

Fakultas Syariah dan Hukum UIN Sunan Gunung Djati Bandung Jl. Raya A.H. Nasution No. 105 Cibiru Kota Bandung, 40614

Tlp/Fax: +022-7802278 Faks. 022-7802278

Website http://journal.uinsgd.ac.id/index.php/asy-syariah/index

E-mail: Jurnalasy-syariah@uinsgd.ac.id 